\title{
Standardization of Maturity at Harvest for Nectarine cvs. May Fire, Snow Queen, Silver King and Red Gold
}

\author{
Ghan Shyam Abrol ${ }^{1 *}$, Kamal Singh Thakur ${ }^{1}$, Narayan Singh Thakur ${ }^{1}$ and Neerja Rana ${ }^{2}$ \\ ${ }^{1}$ Dept. of Food Science and Technology, ${ }^{2}$ Dept. of Basic Science, Dr. Y. S. Parmar University of Horticulture and Forestry, \\ Nauni, Solan (173 230), India
}

Article History

Manuscript No. AR899

Received in $5^{\text {th }}$ Sep, 2014

Received in revised form $25^{\text {th }}$ Jan, 2015

Accepted in final form $28^{\text {th }}$ May, 2015

\section{Correspondence to}

"E-mail: ghasnhyamabrol@gmail.com

\section{Keywords}

Standardization, maturity, nectarine cultivars

\begin{abstract}
The present investigations was conducted at the experimental orchard of Horticultural Research Station, Kandaghat district - Solan, Himachal Pradesh, India. during 2011 and 2012. An attempt was made to determine the optimum maturity for harvesting of nectarine cultivars May Fire, Snow Queen, Silver King and Red Gold on the basis of physico-chemical characteristics of the ripened fruit after a ripening period of 7 days under ambient conditions. For assessing maturity, fruits of each variety were harvested at three day intervals commencing from 6 days before the expected harvest date, with the last sampling date being 6 days after the expected harvest date. On the basis of physico-chemical characteristics the optimum time for harvesting of May Fire, Snow Queen, Silver King and Red Gold was found to be $68 \pm 3,83 \pm 3,83 \pm 3$ and $89 \pm 3$ days, from the date of full bloom, respectively. A significant increase in fruit size, weight, volume, pulp: stone ratio, TSS, sugar and carotenoid content was observed with advancement of harvesting period, while, a decrease in firmness, titratable acidity and ascorbic acid content. After a ripening period of 7 days fruits harvested on $3^{\text {rd }}$ harvesting date retained better physico-chemical attributes in comparison to fruits harvested on other dates.
\end{abstract}

\section{Introduction}

Nectarine (Prunus persica var. nucipersica Schneid.) is a smooth-skinned peach of the family Rosaceae. The word nectarine is derived from a Latin word which means Persian plum although they are not plums. The origin of nectarine is a mystery. These has a smooth fruit in contrast to pubescent fruit of peach, was given a species status in the past, but Bailey (1913) considered only a botanical variety (Prunus persica var. nucipersica). In recent times, the cultivation of nectarine, gained popularity among stone fruit growers in the mid hill areas of Himachal Pradesh. The area under different cultivars of nectarines is expanding rapidly as they have a tendency to fetch better prices due to their earlier arrival in the market as they have a relatively shorter growth period. In India, the peach/nectarine is cultivated in an area of 69, 409 hectare with an annual production of 2, 43, 074 tonnes (FAO 2013). However, for better returns, the fruits have to be harvested at the proper stage of their development. As the fruit is a relatively new introduction in the state, there is a lack of information about the maturity indices for different cultivars.
Moreover, maturity indices have to be worked out for specific locations and information generated elsewhere is not applicable in all nectarine growing areas. A good harvesting index for peaches and nectarines is the background skin colour, which turns yellow from green as chlorophyll content decreases (Delwiche and Baumgardner, 1985; Eccher et al., 1994). However, many of the newer cultivars have a red blush, which masks the background colour, making it virtually impossible to visually determine the maturity stage. The use of biochemical characteristics in determination of optimum harvest maturity is therefore of paramount importance. Thus, the present study was therefore carried out to standardize appropriate maturity indices for nectarine cultivars viz., May Fire, Snow Queen, Silver King and Red Gold.

\section{Materials and Methods}

To determine the optimum maturity for harvesting of nectarine cultivars May Fire, Snow Queen, Silver King and Red Gold on the basis of physico-chemical and sensory characteristics of the fruits, an experiemnt was laid out in the experimental orchard of Horticultural Research Station, Kandaghat, district 
- Solan, Himachal Pradesh, India. for procuring fruit samples at periodic intervals during 2011 and 2012 and the pooled data was presented here. Full bloom was considered to be the date on which $50 \%$ or more of the flowers of each shoot were open (Rufat and Dejong, 2001; Mounzer et al., 2008), and counting the number of days from full bloom to harvest was started from this date. To determine the effects of maturity on fruit quality at harvest and after a seven day ripening period under ambient conditions, fruits from the cultivars May Fire, Snow Queen, Silver King and Red Gold were harvested at five developmental stages, at three days intervals commencing from 6 days before the expected harvest date, with the last sampling date being 6 days after the expected harvest date. Procedures adopted for evaluating quality by measuring physical parameters such as fruit size, weight, specific gravity, pulp: stone ratio as per method prescribed by Ranganna (1986) and observations pertaining to changes in bio-chemical characteristics like Total soluble solids (TSS) were measured using an Erma hand refractometer (0 to $\left.32^{\circ} \mathrm{B}\right)$ and the results were expressed as degree Brix $\left({ }^{\circ} \mathrm{B}\right)$. The readings were corrected by incorporating the appropriate correction factor for temperature variation (Hortwitz 1980). Titratable acidity was estimated by titrating a known aliquot of the sample against $\mathrm{N} / 10 \mathrm{NaOH}$ solution using phenolphthalein as an indicator. The titratable acidity was calculated and expressed as per cent malic acid (AOAC 1980). The total and reducing sugars of fruits were estimated by Lane and Eynon volumetric method (AOAC 1980) by titrating the sample against Fehlings solutions. Changes in antioxidant attributes viz., ascorbic acid content was determined as per AOAC (1980) method using 2, 6-dichlorophenol-indophenol dye and total carotenoids were estimated by macerating a known weight of the sample with acetone and extracting it in petroleum against 3\% acetone in petroleum ether as blank at $452 \mathrm{~nm}$ (Ranganna, 1986). Data pertaining to standardization of maturity indices for different cultivars of nectarines cvs. May Fire, Snow Queen, Silver King and Red Gold were analysed by Randomized Block Design (RBD) with three replications.

\section{Results and Discussion}

\subsection{Date of full bloom and days from full bloom to harvest}

In the present studies the duration of sampling in terms of elapsed days from full bloom (DFFB) to harvest ranged between 64 to $76 / 61$ to 73 days for May Fire, 76 to $88 / 78$ to 90 days for Snow Queen, 77 to $89 / 77$ to 89 days for Silver King and 84 to 96/83 to 95 days for Red Gold during 2011 and 2012, respectively (Table 1a and b). In terms of elapsed days from full bloom to harvest fruits of the cvs. May Fire, Snow Queen, Silver King and Red Gold were considered to be optimally mature after $68 \pm 3,83 \pm 3,83 \pm 3$ and $89 \pm 3$ days, respectively, as fruits from these harvests attained best quality upon ripening.

The days from full bloom to harvest for different cultivars varies as the time required for their growth and maturation is not uniform. Day et al. (2008) reported that the days from bloom to harvest ranges for different cultivars of peach and nectarine viz., Spring bright, Summer Fire and August Red were 104, 140 and 169, respectively. The nectarine cvs Harflame takes 101 days while Harblaze takes 104 days from full bloom to harvest (Cline and Norton, 2012). The growth pattern in nectarine fruit follows a double sigmoid growth curve and growth continues up to the stage of harvest maturity. Fruit length is ceased at this stage of development and then diameter starts showing an increase. During the present investigations, it was observed that in all the cultivars fruit size (length and diameter) and weight increased substantially during the initial sampling dates, which became less prominent with each successive sampling date. However, increases in fruit weight were significant up to the $5^{\text {th }}$ picking dates in all the cultivars May Fire, Snow Queen, Silver King and Red Gold, respectively. A comparison of the growth curves for various parts of Elberta peach showed that the double sigmoid growth curve is expressed by the pericarp tissues and the time at which the first growth period ends approximately coincides with the completion of nucellar growth and commencement

Table 1a: Full bloom dates, harvesting dates and days from full bloom to harvest of nectarine cvs. May Fire and Snow Queen at various maturity stages

\begin{tabular}{|c|c|c|c|c|c|c|c|c|c|c|c|}
\hline \multicolumn{6}{|c|}{ May Fire } & \multicolumn{6}{|c|}{ Snow Queen } \\
\hline \multicolumn{3}{|c|}{2011} & \multicolumn{3}{|c|}{2012} & \multicolumn{3}{|c|}{2011} & \multicolumn{3}{|c|}{2012} \\
\hline $\begin{array}{c}\text { Full bloom } \\
\text { date }\end{array}$ & $\mathrm{HD}^{*}$ & $\begin{array}{c}\text { DFFB to } \\
\text { harvest }\end{array}$ & $\begin{array}{c}\text { Full bloom } \\
\text { date }\end{array}$ & HD & $\begin{array}{c}\text { DFFB to } \\
\text { harvest }\end{array}$ & $\begin{array}{c}\text { Full bloom } \\
\text { date }\end{array}$ & HD & $\begin{array}{c}\text { DFFB to } \\
\text { harvest }\end{array}$ & $\begin{array}{c}\text { Full bloom } \\
\text { date }\end{array}$ & HD & $\begin{array}{c}\text { DFFB to } \\
\text { harvest }\end{array}$ \\
\hline 27, & $02 / 05$ & 64 & 4, March & $04 / 05$ & 61 & 12, March & $27 / 05$ & 76 & 12, March & $29 / 05$ & 78 \\
\hline \multirow[t]{4}{*}{ February } & $05 / 05$ & 67 & & $07 / 05$ & 64 & & $30 / 05$ & 79 & & $01 / 06$ & 81 \\
\hline & $08 / 05$ & 70 & & $10 / 05$ & 67 & & $02 / 06$ & 82 & & $04 / 06$ & 84 \\
\hline & $11 / 05$ & 73 & & $13 / 05$ & 70 & & $05 / 06$ & 85 & & $07 / 06$ & 87 \\
\hline & $14 / 05$ & 76 & & $16 / 05$ & 73 & & $08 / 06$ & 88 & & $10 / 06$ & 90 \\
\hline
\end{tabular}

*HD: Harvest date 
of embryo growth. A possible explanation for the slow growth in phase-II is probably due to the fact that most hardening of the endocarp occurs during this period when the requirement of nutrients for this process might account for retardation of the growth of the fleshy mesocarp (Hulme, 1972). Kurnaz and Kaska (1991) observed that the increase in fruit weight and volume showed double sigmoid curves in peach and nectarine cultivars. They also noticed that fruit flesh density increased rapidly from the end of stage II to the beginning of stage III and thereafter, decreased.

\subsection{Effect of maturity at harvest on physical characteristics of fruit}

The data on fruit weight of different nectarine cultivars indicates that there was a progressive and significant increase in fruit weight of all the cultivars with each successive harvest date (Table 2). The increase in weight generally narrowed down with successive harvests although they continued to be significant throughout sampling. During ripening for 7 days under ambient conditions, the fruit weight exhibited a decline irrespective of their harvesting dates. The decline was maximum in fruits from the first harvest date and generally decreased as fruit became more mature. The physiological loss in weight (PLW) of fruit during the seven day ripening period was recorded to be higher in fruits from earlier sampling dates in all the cultivars (Table 3 ). Therefore, the maximum increase in weight loss after seven days was observed in fruits from the first picking dates and it was recorded to be $14.37,12.75,11.42$ and $10.40 \%$ in the cultivars Silver King, May Fire, Snow Queen and Red Gold, respectively. Physiological loss in weight decreased significantly with each sampling date, and it was observed to be lowest on the last sampling date for all the cultivars. A continuous increase in the pulp: stone ratio was observed in all the cultivars with each successive harvesting date (Table 3 ). The increase was significant up to the $5^{\text {th }}$ harvesting date in the cvs. May Fire, Snow Queen, Silver King and Red Gold. The maximum pulp: stone ratio was recorded in May Fire (12.20), followed by Silver King (11.50), Snow Queen (10.50) and Red Gold (6.60) on the last sampling date.

Physiological loss in weight decreased significantly with advancement of maturity in all the cultivars. Loss in weight during storage and ripening can be attributed to loss of moisture through evapo-transpiration and also to respiratory losses which accounts for utilization of stored food reserves. The decrease in PLW of fruits with increasing maturity might be due to the formation of a natural waxy layer concomitant to maturation, which could help in reduction of moisture and

Table 1b: Full bloom dates, harvesting dates and days from full bloom to harvest of nectarine cvs. Silver King and Red Gold at various maturity stages

\begin{tabular}{|c|c|c|c|c|c|c|c|c|c|c|c|}
\hline \multicolumn{6}{|c|}{ Silver King } & \multicolumn{6}{|c|}{ Red Gold } \\
\hline \multicolumn{3}{|c|}{2011} & \multicolumn{3}{|c|}{2012} & \multicolumn{3}{|c|}{2011} & \multicolumn{3}{|c|}{2012} \\
\hline $\begin{array}{l}\text { Full bloom } \\
\text { date }\end{array}$ & $\mathrm{HD}$ & $\begin{array}{c}\text { DFFB to } \\
\text { harvest }\end{array}$ & $\begin{array}{c}\text { Full bloom } \\
\text { date }\end{array}$ & HD & $\begin{array}{c}\text { DFFB to } \\
\text { harvest }\end{array}$ & $\begin{array}{c}\text { Full bloom } \\
\text { date }\end{array}$ & $\mathrm{HD}$ & $\begin{array}{c}\text { DFFB to } \\
\text { harvest }\end{array}$ & $\begin{array}{c}\text { Full bloom } \\
\text { date }\end{array}$ & HD & $\begin{array}{c}\text { DFFB to } \\
\text { harvest }\end{array}$ \\
\hline \multirow[t]{5}{*}{ 9, March } & $25 / 05$ & 77 & 7, March & $23 / 05$ & 77 & 18, March & $10 / 06$ & 84 & 16, March & 07/06 & 83 \\
\hline & $28 / 05$ & 80 & & $26 / 05$ & 80 & & $13 / 06$ & 87 & & $10 / 06$ & 86 \\
\hline & $31 / 05$ & 83 & & $29 / 05$ & 83 & & $16 / 06$ & 90 & & $13 / 06$ & 89 \\
\hline & $03 / 05$ & 86 & & $01 / 06$ & 86 & & $19 / 06$ & 93 & & $16 / 06$ & 92 \\
\hline & $06 / 05$ & 89 & & $04 / 06$ & 89 & & $22 / 06$ & 96 & & $19 / 06$ & 95 \\
\hline
\end{tabular}

Table 2: Effect of maturity at harvest on changes in fruit weight $(\mathrm{g})$ of nectarine fruit during the 7 day ripening period

\begin{tabular}{|c|c|c|c|c|c|c|c|c|c|c|c|c|}
\hline \multirow{3}{*}{$\begin{array}{l}\text { Harvest dates } \\
(\mathrm{H}) \text { (DFFB) }\end{array}$} & \multicolumn{3}{|c|}{ May Fire } & \multicolumn{3}{|c|}{ Snow Queen } & \multicolumn{3}{|c|}{ Silver King } & \multicolumn{3}{|c|}{ Red Gold } \\
\hline & \multicolumn{3}{|c|}{ Storage duration in days } & \multicolumn{3}{|c|}{ Storage duration in days } & \multicolumn{3}{|c|}{ Storage duration in days } & \multicolumn{3}{|c|}{ Storage duration in days } \\
\hline & 0 & 7 & Mean & 0 & 7 & Mean & 0 & 7 & Mean & 0 & 7 & Mean \\
\hline $\mathrm{H}_{1}$ & 57.1 & 43.6 & 50.4 & 66.3 & 55.2 & 60.8 & 72.8 & 63.0 & 67.9 & 56.4 & 49.1 & 52.8 \\
\hline $\mathrm{H}_{2}$ & 58.7 & 47.8 & 53.3 & 68.5 & 59.8 & 64.1 & 74.8 & 63.8 & 69.3 & 58.5 & 51.4 & 55.0 \\
\hline $\mathrm{H}_{3}$ & 63.4 & 53.6 & 58.5 & 70.1 & 60.8 & 65.4 & 76.4 & 67.2 & 71.8 & 60.7 & 51.9 & 56.3 \\
\hline $\mathrm{H}_{4}$ & 65.2 & 56.5 & 60.9 & 72.3 & 64.9 & 68.6 & 77.5 & 68.7 & 73.1 & 62.2 & 54.5 & 58.4 \\
\hline $\mathrm{H}_{5}$ & 66.5 & 57.5 & 62.0 & 73.5 & 66.2 & 69.9 & 78.3 & 69.7 & 74.0 & 63.2 & 56.1 & 59.7 \\
\hline Mean & 62.2 & 51.8 & & 70.1 & 61.4 & & 76.0 & 66.5 & & 60.2 & 52.6 & \\
\hline \multirow[t]{3}{*}{$\mathrm{CD}(p=0.05)$} & $\mathrm{H}$ & & 0.18 & & & 0.18 & & & 0.17 & & & 0.16 \\
\hline & I & & 0.29 & & & 0.28 & & & 0.27 & & & 0.26 \\
\hline & $\mathrm{H} \times \mathrm{I}$ & & 0.41 & & & 0.40 & & & 0.38 & & & 0.36 \\
\hline
\end{tabular}


respiratory losses, as such a layer is reported to be formed during maturation in many fruits (Wills et al., 1980). The fruits picked at optimal harvest time lose less weight during storage than fruits picked too early but the PLW increased progressively with increase in storage period in peaches (Gupta and Jawandha, 2010).

With the increase in sampling period a significant increase in fruit volume of all the cultivars was observed (Table 4). The maximum fruit volume was recorded in Silver King $(71.1 \mathrm{cc})$ whereas it was minimum in May Fire $(56.5 \mathrm{cc})$. During the 7 day ripening period a significant decline in fruit volume was observed in all the nectarine cultivars. The decrease was highest in May Fire followed by Snow Queen and Silver King, while the lowest decrease was observed in Red Gold fruit. Fruit firmness $\left(\mathrm{kg} \mathrm{cm}^{-2}\right)$ was maximum in fruits of the $\mathrm{cv}$. Red Gold $\left(7.83 \mathrm{~kg} \mathrm{~cm}^{-2}\right)$ followed by Snow Queen $\left(7.75 \mathrm{~kg} \mathrm{~cm}^{-2}\right)$, Silver King $\left(7.67 \mathrm{~kg} \mathrm{~cm}^{-2}\right)$ and it was minimum in May Fire $\left(7.71 \mathrm{~kg} \mathrm{~cm}^{-2}\right)$ on the first sampling date (Table 5). During the

Table 3: Effect of maturity at harvest on changes in physiological loss in weight (PLW) and pulp: stone ratio of nectarine fruits after the 7 day ripening period

\begin{tabular}{|c|c|c|c|c|c|c|c|c|}
\hline \multirow{2}{*}{$\begin{array}{l}\text { Harvest dates } \\
\text { (H) (DFFB) }\end{array}$} & \multicolumn{4}{|c|}{ PLW } & \multicolumn{4}{|c|}{ Pulp: stone ratio } \\
\hline & May Fire & Snow Queen & Silver king & Red Gold & May Fire & Snow Queen & Silver king & Red Gold \\
\hline $\mathrm{H}_{1}$ & 12.75 & 11.42 & 14.37 & 10.40 & 9.13 & 9.53 & 10.53 & 5.73 \\
\hline $\mathrm{H}_{2}$ & 11.07 & 10.94 & 13.83 & 9.81 & 9.65 & 9.88 & 10.80 & 5.98 \\
\hline $\mathrm{H}_{3}$ & 9.99 & 10.07 & 13.13 & 9.26 & 10.67 & 10.18 & 11.18 & 6.18 \\
\hline $\mathrm{H}_{4}$ & 8.82 & 9.79 & 12.58 & 8.88 & 11.42 & 10.30 & 11.43 & 6.42 \\
\hline $\mathrm{H}_{5}^{4}$ & 8.47 & 9.34 & 12.01 & 8.51 & 12.20 & 10.50 & 11.50 & 6.60 \\
\hline Mean & 10.22 & 10.31 & 13.18 & 9.37 & 10.61 & 10.08 & 11.09 & 6.18 \\
\hline $\mathrm{CD}(p=0.05)$ & 0.03 & 0.03 & 0.02 & 0.02 & 0.09 & 0.12 & 0.06 & 0.05 \\
\hline
\end{tabular}

Table 4: Effect of maturity at harvest on changes in fruit volume (cc) of nectarine fruit during the 7 day ripening period

\begin{tabular}{|c|c|c|c|c|c|c|c|c|c|c|c|c|}
\hline \multirow{3}{*}{$\begin{array}{l}\text { Harvest dates } \\
\text { (H) (DFFB) }\end{array}$} & \multicolumn{3}{|c|}{ May Fire } & \multicolumn{3}{|c|}{ Snow Queen } & \multicolumn{3}{|c|}{ Silver King } & \multicolumn{3}{|c|}{ Red Gold } \\
\hline & \multicolumn{3}{|c|}{ Storage duration in days } & \multicolumn{3}{|c|}{ Storage duration in days } & \multicolumn{3}{|c|}{ Storage duration in days } & \multicolumn{3}{|c|}{ Storage duration in days } \\
\hline & 0 & 7 & Mean & 0 & 7 & Mean & 0 & 7 & Mean & 0 & 7 & Mean \\
\hline $\mathrm{H}_{1}$ & 51.8 & 41.5 & 46.6 & 61.9 & 52.9 & 57.4 & 68.7 & 59.9 & 64.3 & 53.6 & 48.9 & 51.3 \\
\hline $\mathrm{H}_{2}$ & 53.9 & 43.2 & 48.6 & 63.9 & 54.9 & 59.4 & 69.9 & 61.5 & 65.7 & 55.2 & 51.2 & 53.2 \\
\hline $\mathrm{H}_{3}$ & 60.4 & 45.2 & 52.8 & 67.4 & 57.6 & 62.5 & 72.1 & 63.7 & 67.9 & 57.0 & 51.4 & 54.3 \\
\hline $\mathrm{H}_{4}$ & 61.2 & 48.5 & 54.8 & 68.0 & 60.3 & 64.1 & 73.4 & 66.0 & 69.7 & 58.6 & 53.4 & 56.1 \\
\hline $\mathrm{H}_{5}$ & 62.5 & 50.6 & 56.5 & 68.8 & 62.9 & 65.9 & 74.3 & 67.8 & 71.1 & 60.4 & 54.8 & 57.6 \\
\hline Mean & 57.9 & 45.8 & & 66.0 & 57.7 & & 71.7 & 63.8 & & 57.0 & 51.9 & \\
\hline \multirow[t]{3}{*}{$\mathrm{CD}(p=0.05)$} & $\mathrm{H}$ & & 0.35 & & & 0.31 & & & 0.20 & & & 0.64 \\
\hline & I & & 0.55 & & & 0.48 & & & 0.32 & & & 1.01 \\
\hline & $\mathrm{H} \times \mathrm{I}$ & & 0.78 & & & 0.68 & & & 0.45 & & & NS \\
\hline
\end{tabular}

Table 5: Effect of maturity at harvest on changes in fruit firmness $\left(\mathrm{kg} \mathrm{cm}^{-2}\right)$ of nectarine fruits during the 7 day ripening period

\begin{tabular}{|c|c|c|c|c|c|c|c|c|c|c|c|c|}
\hline \multirow{3}{*}{$\begin{array}{l}\text { Harvest dates } \\
\text { (H) (DFFB) }\end{array}$} & \multicolumn{3}{|c|}{ May Fire } & \multicolumn{3}{|c|}{ Snow Queen } & \multicolumn{3}{|c|}{ Silver King } & \multicolumn{3}{|c|}{ Red Gold } \\
\hline & \multicolumn{3}{|c|}{ Storage duration in days } & \multicolumn{3}{|c|}{ Storage duration in days } & \multicolumn{3}{|c|}{ Storage duration in days } & \multicolumn{3}{|c|}{ Storage duration in days } \\
\hline & 0 & 7 & Mean & 0 & 7 & Mean & 0 & 7 & Mean & 0 & 7 & Mean \\
\hline $\mathrm{H}_{1}$ & 7.75 & 6.92 & 7.33 & 7.75 & 6.79 & 7.27 & 7.67 & 6.42 & 7.04 & 7.83 & 6.88 & 7.36 \\
\hline $\mathrm{H}_{2}$ & 7.58 & 6.50 & 7.04 & 7.54 & 6.42 & 6.98 & 7.54 & 6.21 & 6.88 & 7.75 & 6.21 & 6.99 \\
\hline $\mathrm{H}_{3}$ & 7.33 & 5.58 & 6.46 & 7.50 & 5.25 & 6.38 & 7.42 & 5.33 & 6.38 & 7.54 & 5.96 & 6.78 \\
\hline $\mathrm{H}_{4}$ & 7.17 & 4.67 & 5.92 & 7.13 & 4.50 & 5.81 & 7.31 & 4.58 & 5.95 & 7.50 & 5.63 & 6.60 \\
\hline $\mathrm{H}_{5}$ & 6.83 & 4.25 & 5.54 & 6.79 & 4.17 & 5.48 & 7.13 & 4.00 & 5.56 & 7.25 & 5.08 & 6.19 \\
\hline Mean & 7.33 & 5.58 & & 7.34 & 5.43 & & 7.41 & 5.31 & & 7.58 & 5.95 & \\
\hline \multirow[t]{3}{*}{$\mathrm{CD}(p=0.05)$} & $\mathrm{H}$ & & 0.26 & & & 0.13 & & & 0.15 & & & 0.09 \\
\hline & I & & 0.16 & & & 0.08 & & & 0.09 & & & 0.06 \\
\hline & $\mathrm{H} \times \mathrm{I}$ & & 0.36 & & & 0.18 & & & 0.21 & & & 0.13 \\
\hline
\end{tabular}


ripening period of 7 days a significant decrease in firmness was observed in all the four nectarine cultivars with mean values decreasing from 7.30 to $5.51 \mathrm{~kg} \mathrm{~cm}^{-2}$ in May Fire, 7.34 to $5.43 \mathrm{~kg} \mathrm{~cm}^{-2}$ in Snow Queen, 7.19 to $5.30 \mathrm{~kg} \mathrm{~cm}^{-2}$ in Silver King and 7.58 to $5.95 \mathrm{~kg} \mathrm{~cm}^{-2}$ in Red Gold. The average fruit length increased gradually with the advancement in maturity (harvesting dates) in all the cultivars (Table 6). The maximum fruit length was recorded in Silver King, whereas May Fire fruits had the least length. A significant decrease in fruit length was observed in all the cultivars during the ripening period of 7 days as it decreased from 46.92 to $43.85 \mathrm{~mm}$ in the $\mathrm{cv}$. May Fire, 47.92 to $44.13 \mathrm{~mm}$ in Snow Queen, 55.10 to $52.12 \mathrm{~mm}$ in Silver King and 50.91 to $47.73 \mathrm{~mm}$ in Red Gold. With the gradual increase in sampling period a significant increase in

\begin{tabular}{|c|c|c|c|c|c|c|c|c|c|c|c|c|}
\hline \multirow{3}{*}{$\begin{array}{l}\text { Harvest dates } \\
\text { (H) (DFFB) }\end{array}$} & \multicolumn{3}{|c|}{ May Fire } & \multicolumn{3}{|c|}{ Snow Queen } & \multicolumn{3}{|c|}{ Silver King } & \multicolumn{3}{|c|}{ Red Gold } \\
\hline & \multicolumn{3}{|c|}{ Storage duration in days } & \multicolumn{3}{|c|}{ Storage duration in days } & \multicolumn{3}{|c|}{ Storage duration in days } & \multicolumn{3}{|c|}{ Storage duration in days } \\
\hline & 0 & 7 & Mean & 0 & 7 & Mean & 0 & 7 & Mean & 0 & 7 & Mean \\
\hline $\mathrm{H}_{1}$ & 42.92 & 38.21 & 40.56 & 41.85 & 37.40 & 39.62 & 52.69 & 48.88 & 50.79 & 48.26 & 45.35 & 46.82 \\
\hline $\mathrm{H}_{2}$ & 45.07 & 41.84 & 43.46 & 45.86 & 42.22 & 44.04 & 54.95 & 51.12 & 53.04 & 49.29 & 46.56 & 47.94 \\
\hline $\mathrm{H}_{3}^{2}$ & 48.61 & 44.79 & 46.70 & 48.90 & 45.37 & 47.13 & 55.64 & 52.24 & 53.94 & 51.12 & 48.73 & 49.94 \\
\hline $\mathrm{H}_{4}$ & 48.80 & 46.50 & 47.65 & 51.39 & 47.49 & 49.44 & 56.04 & 53.55 & 54.80 & 52.35 & 48.89 & 50.63 \\
\hline $\mathrm{H}_{5}$ & 49.19 & 47.92 & 48.55 & 51.57 & 48.19 & 49.88 & 56.18 & 54.80 & 55.49 & 53.54 & 49.10 & 51.32 \\
\hline Mean & 46.92 & 43.85 & & 47.92 & 44.13 & & 55.10 & 52.12 & & 50.91 & 47.73 & \\
\hline \multirow[t]{3}{*}{$\mathrm{CD}(p=0.05)$} & $\mathrm{H}$ & & 0.06 & & & 0.12 & & & 0.15 & & & 0.15 \\
\hline & I & & 0.03 & & & 0.08 & & & 0.09 & & & 0.10 \\
\hline & $\mathrm{H} \times \mathrm{I}$ & & 0.08 & & & 0.17 & & & 0.21 & & & 0.22 \\
\hline
\end{tabular}

Table 7: Effect of maturity at harvest on changes in diameter $(\mathrm{mm})$ of nectarine fruits during the 7 day ripening period

\begin{tabular}{|c|c|c|c|c|c|c|c|c|c|c|c|c|}
\hline \multirow{3}{*}{$\begin{array}{l}\text { Harvest dates } \\
\text { (H) (DFFB) }\end{array}$} & \multicolumn{3}{|c|}{ May Fire } & \multicolumn{3}{|c|}{ Snow Queen } & \multicolumn{3}{|c|}{ Silver King } & \multicolumn{3}{|c|}{ Red Gold } \\
\hline & \multicolumn{3}{|c|}{ Storage duration in days } & \multicolumn{3}{|c|}{ Storage duration in days } & \multicolumn{3}{|c|}{ Storage duration in days } & \multicolumn{3}{|c|}{ Storage duration in days } \\
\hline & 0 & 7 & Mean & 0 & 7 & Mean & 0 & 7 & Mean & 0 & 7 & Mean \\
\hline$\overline{\mathrm{H}_{1}}$ & 46.42 & 40.09 & 43.25 & 47.57 & 42.50 & 45.03 & 49.53 & 41.46 & 45.49 & 50.20 & 44.92 & 47.56 \\
\hline $\mathrm{H}_{2}$ & 48.56 & 41.94 & 45.25 & 49.74 & 44.46 & 47.10 & 51.95 & 44.17 & 48.06 & 51.95 & 45.20 & 48.57 \\
\hline $\mathrm{H}_{3}$ & 49.95 & 43.41 & 46.68 & 51.95 & 47.20 & 49.57 & 53.89 & 46.51 & 50.20 & 52.83 & 46.15 & 49.49 \\
\hline $\mathrm{H}_{4}$ & 50.30 & 45.59 & 47.94 & 52.51 & 48.94 & 50.73 & 54.12 & 46.65 & 50.38 & 53.37 & 47.02 & 50.20 \\
\hline $\mathrm{H}_{5}$ & 51.92 & 46.83 & 49.37 & 53.10 & 49.54 & 51.32 & 54.32 & 47.00 & 50.66 & 54.10 & 47.37 & 50.73 \\
\hline Mean & 49.43 & 43.57 & & 50.97 & 46.53 & & 52.76 & 45.15 & & 52.49 & 46.13 & \\
\hline \multirow[t]{3}{*}{$\mathrm{CD}(p=0.05)$} & $\mathrm{H}$ & & 0.127 & & & 0.127 & & & 0.123 & & & 0.124 \\
\hline & I & & 0.201 & & & 0.200 & & & 0.195 & & & 0.197 \\
\hline & $\mathrm{H} \times \mathrm{I}$ & & 0.285 & & & 0.284 & & & 0.276 & & & 0.278 \\
\hline
\end{tabular}

Table 8: Effect of maturity at harvest on changes in TSS $\left({ }^{\circ} \mathrm{B}\right)$ of nectarine fruits during the 7 day ripening period

\begin{tabular}{|c|c|c|c|c|c|c|c|c|c|c|c|c|}
\hline \multirow{3}{*}{$\begin{array}{l}\text { Harvest dates } \\
\text { (H) (DFFB) }\end{array}$} & \multicolumn{3}{|c|}{ May Fire } & \multicolumn{3}{|c|}{ Snow Queen } & \multicolumn{3}{|c|}{ Silver King } & \multicolumn{3}{|c|}{ Red Gold } \\
\hline & \multicolumn{3}{|c|}{ Storage duration in days } & \multicolumn{3}{|c|}{ Storage duration in days } & \multicolumn{3}{|c|}{ Storage duration in days } & \multicolumn{3}{|c|}{ Storage duration in days } \\
\hline & 0 & 7 & Mean & 0 & 7 & Mean & 0 & 7 & Mean & 0 & 7 & Mean \\
\hline $\mathrm{H}_{1}$ & 7.5 & 9.9 & 8.7 & 8.1 & 10.3 & 9.2 & 8.4 & 10.3 & 9.4 & 7.2 & 9.4 & 8.3 \\
\hline $\mathrm{H}_{2}$ & 8.0 & 10.4 & 9.2 & 8.7 & 10.8 & 9.8 & 8.8 & 10.8 & 9.8 & 7.9 & 10.0 & 9.0 \\
\hline $\mathrm{H}_{3}$ & 9.1 & 11.7 & 10.4 & 9.5 & 11.7 & 10.6 & 9.4 & 11.5 & 10.5 & 8.5 & 11.3 & 9.9 \\
\hline $\mathrm{H}_{4}$ & 9.2 & 12.4 & 10.8 & 9.8 & 11.8 & 10.8 & 10.0 & 11.8 & 10.9 & 8.9 & 12.1 & 10.5 \\
\hline $\mathrm{H}_{5}^{4}$ & 9.6 & 12.5 & 11.1 & 10.2 & 12.2 & 11.2 & 10.5 & 12.1 & 11.3 & 9.3 & 12.3 & 10.9 \\
\hline Mean & 8.7 & 11.4 & & 9.3 & 11.3 & & 9.4 & 11.3 & & 8.4 & 11.0 & \\
\hline \multirow[t]{3}{*}{$\mathrm{CD}(p=0.05)$} & $\mathrm{H}$ & & 0.10 & & & 0.10 & & & 0.07 & & & 0.20 \\
\hline & I & & 0.06 & & & 0.06 & & & 0.04 & & & 0.12 \\
\hline & $\mathrm{H} \times \mathrm{I}$ & & 0.15 & & & NS & & & 0.10 & & & 0.28 \\
\hline
\end{tabular}


fruit diameter was observed in all the cultivars (Table 7). The increase in fruit diameter was maximum towards the end of sampling in all the cultivars.

Bassi et al. (1995) recorded increase in fruit size especially in diameter of nectarine cvs. Maria Aurelia and Red Gold. In Red Gold peach, the proportion of fruits having more than $21 \mathrm{~cm}$ diameter increased up to the third sampling date, which was considered during ripening at 3 to 4 days interval. Andersen and

Table 9: Effect of maturity at harvest on changes in titratable acidity (\% malic acid) content of nectarine fruit during the 7 day ripening period

\begin{tabular}{|c|c|c|c|c|c|c|c|c|c|c|c|c|}
\hline \multirow{3}{*}{$\begin{array}{l}\text { Harvest dates } \\
\text { (H) (DFFB) }\end{array}$} & \multicolumn{3}{|c|}{ May Fire } & \multicolumn{3}{|c|}{ Snow Queen } & \multicolumn{3}{|c|}{ Silver King } & \multicolumn{3}{|c|}{ Red Gold } \\
\hline & \multicolumn{3}{|c|}{ Storage duration in days } & \multicolumn{3}{|c|}{ Storage duration in days } & \multicolumn{3}{|c|}{ Storage duration in days } & \multicolumn{3}{|c|}{ Storage duration in days } \\
\hline & 0 & 7 & Mean & 0 & 7 & Mean & 0 & 7 & Mean & 0 & 7 & Mean \\
\hline $\mathrm{H}_{1}$ & 1.24 & 0.95 & 1.10 & 1.37 & 1.13 & 1.25 & 1.47 & 1.21 & 1.34 & 1.25 & 1.04 & 1.15 \\
\hline $\mathrm{H}_{2}$ & 1.08 & 0.86 & 0.97 & 1.22 & 1.05 & 1.14 & 1.29 & 1.14 & 1.21 & 1.13 & 0.89 & 1.01 \\
\hline $\mathrm{H}_{3}$ & 1.00 & 0.75 & 0.87 & 1.11 & 0.96 & 1.03 & 1.16 & 0.93 & 1.05 & 1.05 & 0.79 & 0.92 \\
\hline $\mathrm{H}_{4}$ & 0.93 & 0.66 & 0.80 & 1.01 & 0.86 & 0.94 & 1.07 & 0.82 & 0.94 & 0.95 & 0.69 & 0.82 \\
\hline $\mathrm{H}_{5}$ & 0.86 & 0.56 & 0.71 & 0.96 & 0.74 & 0.85 & 0.99 & 0.73 & 0.86 & 0.88 & 0.61 & 0.75 \\
\hline Mean & 1.02 & 0.75 & & 1.13 & 0.95 & & 1.20 & 0.96 & & 1.05 & 0.80 & \\
\hline \multirow[t]{3}{*}{$\mathrm{CD}(p=0.05)$} & $\mathrm{H}$ & & 0.010 & & & 0.010 & & & 0.011 & & & 0.011 \\
\hline & I & & 0.016 & & & 0.016 & & & 0.018 & & & 0.017 \\
\hline & $\mathrm{H} \times \mathrm{I}$ & & 0.023 & & & 0.023 & & & 0.025 & & & 0.024 \\
\hline
\end{tabular}

Table 10: Effect of maturity at harvest on changes in reducing sugars (\%) content of nectarine fruits during the 7 day ripening period

\begin{tabular}{|c|c|c|c|c|c|c|c|c|c|c|c|c|}
\hline \multirow{3}{*}{$\begin{array}{l}\text { Harvest dates } \\
\text { (H) (DFFB) }\end{array}$} & \multicolumn{3}{|c|}{ May Fire } & \multicolumn{3}{|c|}{ Snow Queen } & \multicolumn{3}{|c|}{ Silver King } & \multicolumn{3}{|c|}{ Red Gold } \\
\hline & \multicolumn{3}{|c|}{ Storage duration in days } & \multicolumn{3}{|c|}{ Storage duration in days } & \multicolumn{3}{|c|}{ Storage duration in days } & \multicolumn{3}{|c|}{ Storage duration in days } \\
\hline & 0 & 7 & Mean & 0 & 7 & Mean & 0 & 7 & Mean & 0 & 7 & Mean \\
\hline $\mathrm{H}_{1}$ & 1.71 & 2.37 & 2.04 & 1.78 & 2.23 & 2.00 & 1.85 & 2.40 & 2.12 & 1.48 & 1.79 & 1.64 \\
\hline $\mathrm{H}_{2}$ & 1.82 & 2.56 & 2.19 & 1.88 & 2.40 & 2.14 & 1.94 & 2.61 & 2.28 & 1.57 & 1.90 & 1.75 \\
\hline $\mathrm{H}_{3}$ & 1.99 & 3.11 & 2.55 & 2.05 & 2.90 & 2.48 & 2.08 & 3.22 & 2.65 & 1.72 & 2.06 & 1.90 \\
\hline $\mathrm{H}_{4}$ & 2.14 & 3.64 & 2.89 & 2.25 & 3.30 & 2.77 & 2.33 & 3.79 & 3.06 & 1.86 & 2.47 & 2.20 \\
\hline $\mathrm{H}_{5}$ & 2.51 & 4.52 & 3.51 & 2.58 & 3.96 & 3.27 & 2.62 & 4.88 & 3.75 & 1.95 & 2.77 & 2.39 \\
\hline Mean & 2.03 & 3.24 & & 2.11 & 2.96 & & 2.16 & 3.38 & & 1.72 & 2.20 & \\
\hline \multirow[t]{3}{*}{$\mathrm{CD}(p=0.05)$} & $\mathrm{H}$ & & 0.13 & & & 0.12 & & & 0.13 & & & 0.12 \\
\hline & I & & 0.08 & & & 0.08 & & & 0.08 & & & 0.08 \\
\hline & $\mathrm{H} \times \mathrm{I}$ & & 0.18 & & & 0.17 & & & 0.18 & & & 0.17 \\
\hline
\end{tabular}

Table 11: Effect of maturity at harvest on changes in total sugars (\%) content of nectarine cvs. May Fire and Snow Queen during the 7 day ripening period

\begin{tabular}{|c|c|c|c|c|c|c|c|c|c|c|c|c|}
\hline \multirow{3}{*}{$\begin{array}{l}\text { Harvest dates } \\
\text { (H) (DFFB) }\end{array}$} & \multicolumn{3}{|c|}{ May Fire } & \multicolumn{3}{|c|}{ Snow Queen } & \multicolumn{3}{|c|}{ Silver King } & \multicolumn{3}{|c|}{ Red Gold } \\
\hline & \multicolumn{3}{|c|}{ Storage duration in days } & \multicolumn{3}{|c|}{ Storage duration in days } & \multicolumn{3}{|c|}{ Storage duration in days } & \multicolumn{3}{|c|}{ Storage duration in days } \\
\hline & 0 & 7 & Mean & 0 & 7 & Mean & 0 & 7 & Mean & 0 & 7 & Mean \\
\hline $\mathrm{H}_{1}$ & 3.28 & 3.60 & 3.44 & 3.67 & 3.99 & 3.83 & 3.83 & 4.22 & 4.02 & 3.11 & 3.39 & 3.25 \\
\hline $\mathrm{H}_{2}$ & 3.34 & 3.71 & 3.52 & 3.78 & 4.14 & 3.96 & 3.96 & 4.47 & 4.21 & 3.19 & 3.49 & 3.35 \\
\hline $\mathrm{H}_{3}$ & 3.45 & 3.85 & 3.65 & 3.95 & 4.33 & 4.14 & 4.11 & 4.70 & 4.41 & 3.32 & 3.62 & 3.49 \\
\hline $\mathrm{H}_{4}$ & 3.57 & 4.09 & 3.83 & 4.09 & 4.52 & 4.30 & 4.28 & 5.07 & 4.68 & 3.48 & 3.76 & 3.63 \\
\hline $\mathrm{H}_{5}$ & 3.69 & 4.32 & 4.01 & 4.28 & 4.71 & 4.49 & 4.51 & 5.47 & 4.99 & 3.61 & 3.95 & 3.79 \\
\hline Mean & 3.46 & 3.91 & & 3.96 & 4.34 & & 4.14 & 4.78 & & 3.34 & 3.64 & \\
\hline \multirow[t]{3}{*}{$\mathrm{CD}(p=0.05)$} & $\mathrm{H}$ & & 0.05 & & & 0.02 & & & 0.05 & & & 0.01 \\
\hline & I & & 0.03 & & & 0.01 & & & 0.03 & & & 0.01 \\
\hline & $\mathrm{H} \times \mathrm{I}$ & & 0.07 & & & 0.02 & & & 0.08 & & & 0.02 \\
\hline
\end{tabular}


Sherman (1995) observed that Suncoast nectarine fruit ripened during the first week of May after a development period of 75-80 days in northern Florida with average fruit diameter 6 $\mathrm{cm}$ and weight $>100 \mathrm{~g}$. Sherman et al. (1995) further observed that the average diameter of fruits was $5.5 \mathrm{~cm}$ and fruit weight was 90-100 g in Sunmist nectarine when fruits were picked at commercial harvest date.

\subsection{Bio-chemical characteristics}

Total soluble solid (TSS) content of fruits increased with a progressive increase in harvesting dates (Table 8 ). The lowest TSS values were recorded on the first harvesting dates and these values increased gradually with each successive harvest and became maximum by the last harvesting dates. During the 7 day ripening period the maximum TSS content was observed in fruits that were sampled on the 5th harvesting dates in all the cultivars viz., May Fire $\left(12.5^{\circ} \mathrm{B}\right)$, Snow Queen $\left(12.2^{\circ} \mathrm{B}\right)$, Silver King $\left(12.1^{\circ} \mathrm{B}\right)$ and Red Gold $\left(12.3^{\circ} \mathrm{B}\right)$. A similar trend was observed in the reducing and total sugar contents with change in maturity and during ripening as fruits of different cultivars exhibited maximum reducing and total sugar contents upon ripening when they were harvested on the $5^{\text {th }}$ sampling date. During ripening for 7 days under ambient conditions the titratable acidity content of fruits harvested on different dates exhibited a decline although, fruits harvested earlier retained higher acid contents than those harvested later (Table 9).

Table 10, reveals that there was a significant increase in reducing sugar content of all the cultivars with a delay in harvesting from the $1^{\text {st }}$ to the $5^{\text {th }}$ sampling date. On the first sampling date the reducing sugar contents were lowest in the cv. Red Gold (1.48\%) and highest in Silver King (1.85\%).
Similarly the mean reducing sugar contents on the date of harvest were also minimum in Red Gold $(1.72 \%)$ and maximum in Silver King (2.16\%). Fruits from the $5^{\text {th }}$ harvest recorded the maximum total sugars content after ripening, recording values of 4.32, 4.71, 5.47 and $3.95 \%$ for the cvs. May Fire, Snow Queen Silver King and Red Gold, respectively (Table 11). These harvest dates also resulted in maximum mean values for total sugar contents in different cultivars.

The lowest TSS values were recorded on the first harvesting dates and these values increased gradually with each successive harvest and became maximum by the last harvesting dates. As the fruit mature on the tree, glucose and fructose are converted into sucrose, the predominant sugar in the ripe fruit. In fruit that were mature and had a higher mass at harvest, the total sugars and the proportion of sucrose were higher, while the proportions of glucose and fructose were lower. This confirms that the total amount of sugars increased and that glucose and fructose were converted into sucrose while the peach fruit matured on the tree (Kobashi et al., 1999; Moriguchi et al., 1990).

\subsection{Antioxidant properties}

Ascorbic acid content of fruits decreased throughout harvesting in all the cultivars as the fruits harvested earlier contained more vitamin-C than those harvested at a later stage of maturity (Figure 1). During ripening under ambient conditions there was a rapid and significant loss in ascorbic acid contents in all the cultivars which was more pronounced in fruits from the first harvest and comparatively slower in fruits harvested

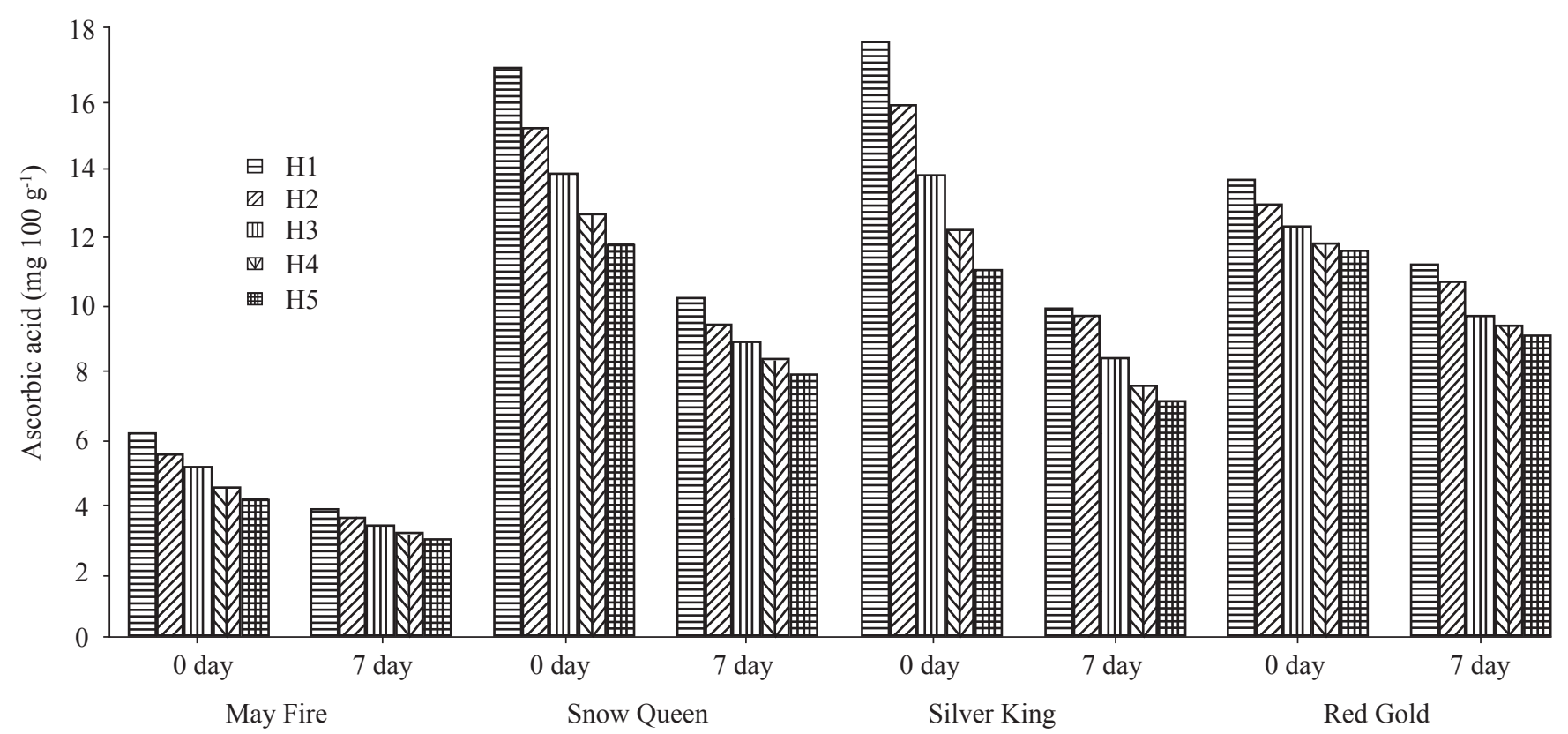

Figure 1: Effect of maturity at harvest on changes in ascorbic acid $\left(\mathrm{mg} 100 \mathrm{~g}^{-1}\right)$ content of nectarine fruits during the 7 day ripening period 


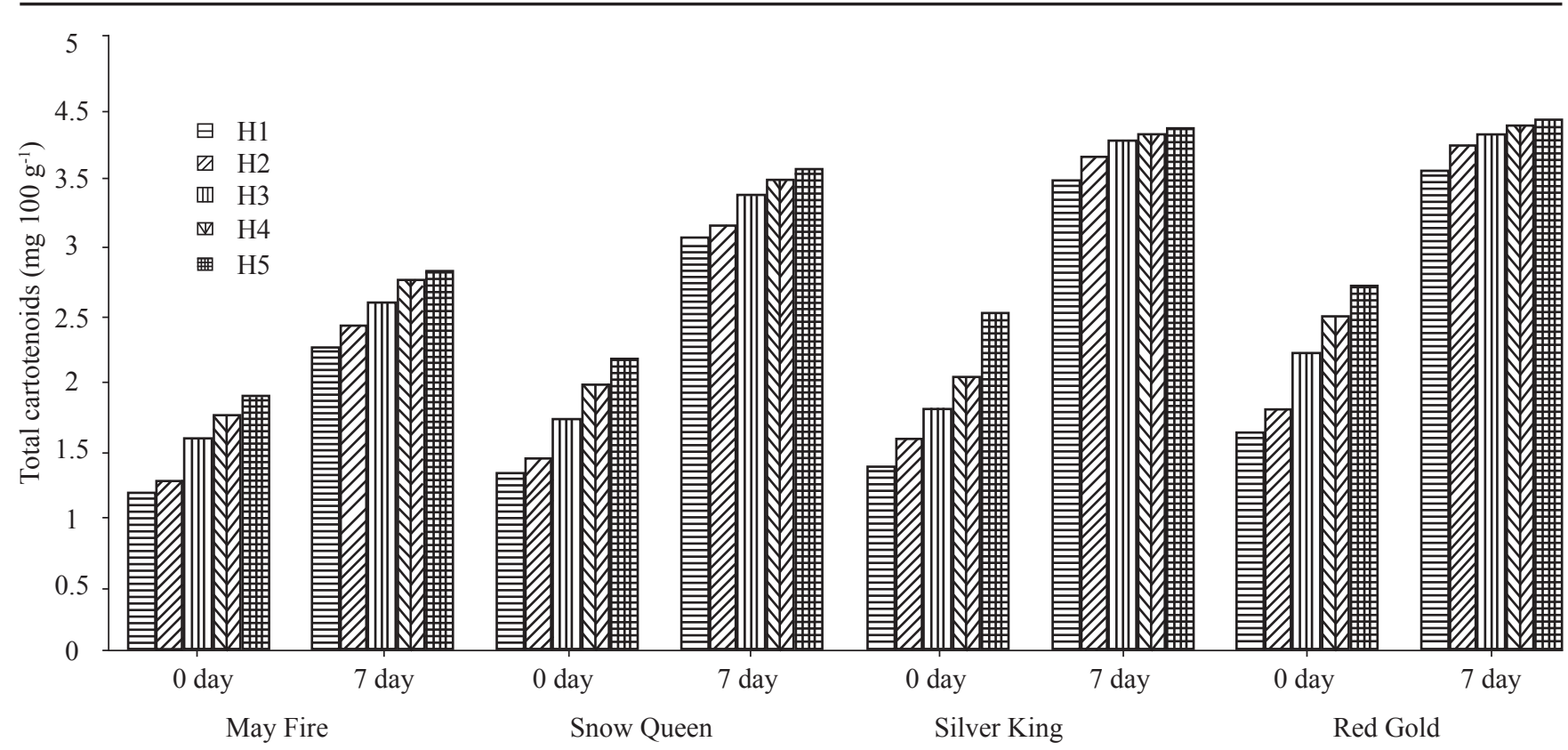

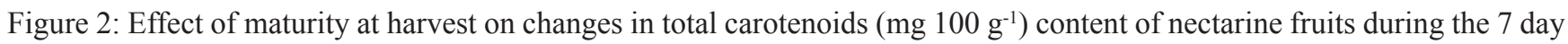
ripening period

at later stages. The mean ascorbic acid level were observed to be highest on the first sampling date with values of 12.97 mg $100 \mathrm{~g}^{-1}$ in Silver King, $12.78 \mathrm{mg} 100 \mathrm{~g}^{-1}$ in Snow Queen,

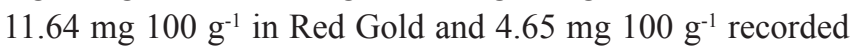
in the cv. May Fire.

A gradual decline in the titratable acidity and ascorbic acid content of fruits occurred with every successive picking date in all the cultivars. Babu and Yadav (2002) observed that fruits harvested at 82-96 days after fruit set had the lowest titratable acidity $(0.67 \%)$ in peach cv. Shan-i-Punjab. They also observed that there was no significant in-crease in fruit quality after 82 days after full bloom in Shan-e-Punjab cultivar of peach grown under Meghalaya conditions. Ma et al. (2003) showed that flat peach (Prunus persica var. compressa) had a sweet taste and low ti-tratable acidity (less than $0.4 \%$ ). Park and Kim (2002) observed that flesh firmness decreases and soluble solids contents increases with the fruit maturity. The variation in acidity, attributed to fruit maturity, did not show a spe-cific trend in two nectarine cultivars viz., Subong and Cheonhong. The titratable acidity of $0.58 \%$ and $0.61 \%$ were recorded in Flordasun and Pratap cvs. of peach at ripening stage (Bhatnagar and Kaul, 2002); Carlos et al. (2003) reported that in nectarine cv. Spring Bright fruit soluble solids concentrations varied from 8.0 to $16.0 \%$ with a mean of value of $11.0 \%$ and titratable acidity ranged from 0.60 to $1.20 \%$ with a mean of $0.92 \%$. Whereas, in Elegant Lady cultivar of peach, soluble solids concentrations varied from 9.0 to $15.0 \%$ with a mean of $12.4 \%$ and titratable acidity ranged from 0.45 to $0.90 \%$ with a mean of $0.74 \%$ as reflected by the consumer test.
The total carotenoid contents increased gradually with advancement of harvesting period (Figure 2). The lowest mean total carotenoids were recorded on the first sampling date whereas the values were highest on the last sampling date in all the cultivars. During the 7 day ripening period, the total carotenoid content increased in all the cultivars.

\section{Conclusion}

Optimum time for harvesting of May Fire, Snow Queen, Silver King and Red Gold was found to be $68 \pm 3,83 \pm 3,83 \pm 3$ and $89 \pm 3$ days, from the date of full bloom, respectively. A significant increase in fruit size, weight, volume, pulp: stone ratio, TSS, sugar and carotenoid content was observed with advancement of harvesting period, while, a decrease in firmness, titratable acidity and ascorbic acid content. After a ripening period of 7 days, $3^{\text {rd }}$ harvesting date fruits retained better physico-chemical attributes.

\section{References}

Andersen, P.C., Sherman, W.B., 1995. 'Suncoast' nectarine. Hort Science 30(2), 383-384.

AOAC. 2000. Official Methods of Analysis. Association of Official Analytical Chemists, Washington, DC, USA.

Babu, K.D., Yadav, D.S., 2002. Fruit growth and development of peach cv. Shan-i-Punjab under edaphic and environmental conditions of Meghalaya. Indian Journal of Horticulture 59(1), 44-48.

Bailey, L.H., 1913. The Standard Encyclopedia of Horticulture. The McMillan Company, New York. 
Bassi, D., Corelli, G.L., Ravaglia, G., Giusti, I., 1995. Evoluzione della maturazione in due nettarine. Atti XXII Convegno Peschicolo, Cesena, Italy, 28-30 September 1995, 66-70.

Bhatnagar, P., Kaul, M.K., 2002. Growth and development studies in peach (Prunus persica Batsch) cvs. Pratap, Floardasun and Shan-i-Punjab. Journal of Eco Physiology 5(3/4), 93-95.

Carlos, H.C., Gayle, C., Earl, B., 2003. Understanding consumer acceptance of peach, nectarine and plum cultivars. Acta Horticulturae 604, 115-119.

Cline, J.A., Norton, D., 2012. Performance of 17 peach and nectarine cultivars in a southern-ontario, non-traditional growing region. Journal of the American Pomological Society 66(3) 133-144.

Day, K., Lopez, G., DeJong, T., 2008. Using growing degree hours accumulated thirty days after bloom to predict peach and nectarine harvest date. Acta Horticulturae 803, 163-166.

Delwiche, M.J., Baumgardner, A., 1985. Ground colour as a peach maturity index. Journal of American Society of Horticultural Sciences 110, 53-57.

Eccher, Zerbini, P., Spada, G.L., Liverani, C., 1994. Selection and experimental use of color charts as a maturity index for harvesting peaches and nectarines. Advances of Horticultural Science 8, 107-113.

FAO, 2013. http://faostat.fao.org/site/567/DesktopDefault. aspx? Page $\mathrm{ID}=567 \#$ ancor.

Gupta, N., Jawandha, S.K., 2010. Influence of Maturity Stage on Fruit Quality during Storage of 'Earli Grande' Peaches. Notulae Scientia Biologicae 2(3), 96-99.

Hortwitz, W., 1980. Official Methods of Analysis, $13^{\text {th }}$ edn. Association of Annual Chemistry, Washington, D.C.

Hulme, A.C., 1972. The biochemistry of fruits and their products. Ed. Vol. I. Academic Press, London and New York.

Kobashi, K., Gemma, H., Iwahori, S., 1999. Sugar accumulation in peach fruit as affected by abscisic acid (ABA) treatment in relation to some sugar metabolizing enzymes. Journal of the Japanese Society for Horticultural Science 68, 465-470.

Kurnaz, S., Kaska, N., 1991. Physical changes in fruits of some peach and nectarine cultivars during growth, under ecological conditions of Adana and Pozanti. Doga, Turk Tarim ve Ormancilic Dergisi 15(2), 384-405.

Ma, R., Yu, M., Du, P., Guo, H., Song, H., 2003. Evaluation of germplasm resources and breeding of flat peach. Acta Horticulturae 620, 161-167. DOI:10.17660/ ActaHortic.2003.620.16.

Moriguchi, T., Sanada, T., Yamaki, S., 1990. Seasonal fluctuations of some enzymes relating to sucrose and sorbitol metabolism in peach fruit. Journal of American Society for Horticultural Science 115, 278-281.

Mounzer, O.H., Conejero, W., Nicolas, E., Abrisqueta, I., Garcia-Orellana, Y.V., Tapia, L.M., Vera, J., Abrisqueta, J.M., Ruiz-Sanchez, M., del, C., 2008. Growth pattern and phenological stages of early-maturing peach trees under a Mediterranean climate. HortScience 43(6), 1813-1818.

Park, Youn Moon., Kim, JongJu., 2002. Correlation analysis among quality attributes for practical harvest indices of nectarine fruits. Korean Journal of Horticultural Science and Technology 20(3), 225-229.

Ranganna, S., 1986. Handbook of Analysis and Quality Control of Fruit and Vegetable Products. $2^{\text {nd }}$ ed. Tata McGraw Hill Publication Company, New Delhi.

Rufat, J., Dejong, T.M., 2001. Estimating seasonal nitrogen dynamics in peach trees in response to nitrogen availability. Tree Physiology 21, 1133-1140.

Sherman, W.B., Andersen, P.C., Lyrene, P.M., 1995. 'Sunmist' nectarine. Hort Science 30(1), 155.

Wills, R.B.H., Bembridge, P.A., Scott, K.J., 1980. Use of flesh firmness and other objective tests to determine consumer acceptability of Delicious apple. Australian Journal of Experimental Agriculture and Animal Husbandry 20, 252-256. 